\title{
Correction: DNA methylation patterns associate with genetic and gene expression variation in HapMap cell lines
}

Jordana T Bell ${ }^{1,3^{*}}$, Athma A Pai ${ }^{1}$, Joseph K Pickrell ${ }^{1}$, Daniel J Gaffney ${ }^{1,2}$, Roger Pique-Regi ${ }^{1}$, Jacob F Degner ${ }^{1}$, Yoav Gilad ${ }^{1 *}$ and Jonathan K Pritchard ${ }^{1,2^{*}}$

\section{Correction}

We showed in our study [1] that SNP rs10876043 in the disco-interacting protein 2 homolog $\mathrm{B}$ gene $(D I P 2 B)$ was associated with the first principal component of methylation. Although the analyses and result remain unchanged, it appears that this observation is likely due to a genotyping artifact. That is, the reported rs10876043 genotypes differ according to HapMap Phase (cell lines genotyped in Phase $1 / 2$ have reported genotypes AG and GG, while Phase 3 cell lines have genotype AA). The 1000 Genomes data suggest the correct genotype is probably AA for all of these YRI individuals. These genotype differences between different phases of the HapMap Project, coupled with a small difference in mean methylation between Phase $1 / 2$ vs 3 cell lines appear to have produced an artifactual association. Other analyses in the paper controlled for the top principal components and should therefore be robust to this type of effect.

\section{Acknowledgements}

We thank Lude Franke and Harm-Jan Westra (Department of Genetics, University Medical Centre Groningen) for bringing this to our attention.

\section{Author details}

'Department of Human Genetics, The University of Chicago, 920 E. 58th St, Chicago, IL 60637, USA. ${ }^{2}$ Howard Hughes Medical Institute, The University of Chicago, 920 E. 58th St, Chicago, IL 60637, USA. ${ }^{3}$ Current address: Wellcome Trust Centre for Human Genetics, University of Oxford, Roosevelt Drive, Oxford OX3 7BN, UK.

Published: 3 July 2011

* Correspondence: jordana@well.ox.ac.uk; gilad@uchicago.edu; pritch@uchicago.edu

'Department of Human Genetics, The University of Chicago, 920 E. 58th St, Chicago, IL 60637, USA

Full list of author information is available at the end of the article

\section{Reference}

1. Bell JT, Pai AA, Pickrell JK, Gaffney DJ, Pique-Regi R, Degner JF, Gilad Y, Pritchard JK: DNA methylation patterns associate with genetic and gene expression variation in HapMap cell lines. Genome Biol 2011, 12:R10.

doi:10.1186/gb-2011-12-6-405

Cite this article as: Bell et al:: Correction: DNA methylation patterns associate with genetic and gene expression variation in HapMap cell lines. Genome Biology 2011 12:405.
Submit your next manuscript to BioMed Central and take full advantage of:

- Convenient online submission

- Thorough peer review

- No space constraints or color figure charges

- Immediate publication on acceptance

- Inclusion in PubMed, CAS, Scopus and Google Scholar

- Research which is freely available for redistribution
C Biomed Central 